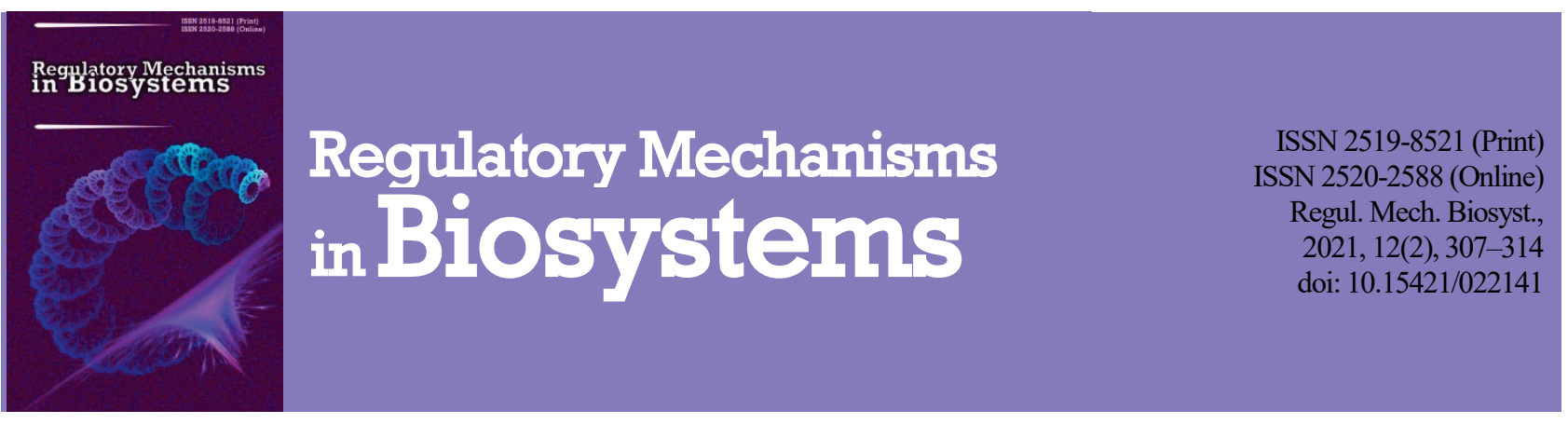

\title{
Effect of extract from common oat on the antioxidant activity and fatty acid composition of the muscular tissues of geese
}

\author{
O. O. Danchenko*, Y. V. Nicolaeva**, O. I. Koshelev**, M. M. Danchenko*, O. V. Yakoviichuk**, T. I. Halko** \\ *Dmytro Motornyi Tavria State Agrotechnological University, Melitopol, Ukraine \\ **Bogdan Khmelnitsky Melitopol State Pedagogical University, Melitopol, Ukraine
}

Article info

Received 02.04.2021

Received in revised form 04.05 .2021

Accepted 05.05.2021

\section{Dimytro Motornyi}

Tavria State

Agrotechnological University

B.Khmelnytsky Ave, 18,

Melitopol, 72312, Ukraine.

Tel:+38-096-885-94-17

Bogdan Khmelnitsky

Melitopol State

Pedagogical University,

Hetmanska St, 20, Melitopol,

72300, Ukraine.

Tel: +38-098-558-37-55

E-mail:

aikoshelev4971@gmail.com
E-mail:nndea@ukr.net

Danchenko, O. O., Nicolaeva, Y. V., Koshelev, O. I., Danchenko, M. M., Yakovïchuk, O. V., \& Halko, T. I. (2021). Effect of extract from common oat on the antioxidant activity and fatty acid composition of the muscular tissues of geese. Regulatory Mechanisms in Biosystems, 12(2), 307-314. doi:10.15421/022141

Among natural antioxidants, increasing attention is being drawn to avenanthramides - phenolic compounds of the common oat $A v e-$ na sativa (Linnaeus, 1753). Research has shown that avenanthramides have much higher antioxidant activity than well-known bioflavanoids. Currently, a great deal of work is being conducted on the structure of these compounds and mechanisms of their effect on the organism of humans and animals. We explored the specifics of the influence of aqueous extract from $A$. sativa on the antioxidant activity and fatty acid composition of lipids of histologically similar tissues of geese with different levels of aerobicity (muscles of the stomach and cardiac muscle), dynamics of the birds' live weight and pterylographic parameters under physiological loading by the development of contour and juvenile feathers. The addition of extract of oat to the diet of geese during growth of feathers was observed to increase the antioxidant activity of their tissues. Physiological loading related to the development of contour feathers in the examined tissues of geese significantly weakens as a result of selective inhibition of synthesis of unsaturated fatty acids, especially oleic acid, the content of which in 28-day old geese of the experimental group decreased by 31.7 in the cardiac muscle and 46.8 times in the stomach, compared with the control. Further changes in fatty acid composition were characterized by lower number of differences between the control and experimental groups. Increase in antioxidant activity in these tissues during development of juvenile feathers (day 49) occurs as a result of activation of alternative mechanisms of antioxidative protection, which take place with no significant changes in fatty acid composition. Furthermore, we determined that in the stomach and cardiac muscles of geese, the action of extract from common oat activated mechanisms of antioxidative protection, which increased the level of correlation between the changes in fatty acid composition. The study confirmed that the extract caused not only significant increase in the weight of geese at the end of the experiment, but also improved their pterylographic parameters. Therefore, it is practical to conduct similar studies on wild species of birds grown for hunting, because this process of development of feathers, particularly for such species of birds, is essential.

Keywords: stomach muscles; cardiac muscle; physiological pressure; level of correlation of changes in fatty acid composition; pterylogaphic parameters.

\section{Introduction}

Use of antioxidants in poultry nutrition helps in eliminating the harmful impact of negative factors of various etiologies. Application of natural antioxidant supplements to feeding of birds has a number of advantages over the traditional synthetic additives. Currently, scientists from all around the world are drawing attention to the uniqueness of the complex of biologically active compounds in the content of the common oat Avena sativa (Singh et al., 2013; Montilla-Bascón et al., 2017; Jágr et al., 2020). And there are good reasons for this. Among the well-known phenolic compounds, avenanthramides, compounds with a broad range of biochemical action found exclusively in oats, have become especially significant in recent years (Aldubayan et al., 2019; De Bruijn et al., 2019; Sumayya et al., 2021). Avenanthramides are poly-functional compounds because of their molecules that contain not only the phenol hydroxyl group, but amino- and carboxyl-groups as well (Walsh et al., 2017; Pridal et al., 2018; Chen et al., 2018). The presence of a single electronic chain of benzol nuclei and double bonds in molecules of avenanthramides (Soycan et al., 2019; Chen et al., 2020; Ltaif et al., 2020) determines the extremely high thermodynamic stability of their radicals. Antioxidant activity of these substances was confirmed to be 10-30 times higher than that of well-known bioflavanoids (Nie et al., 2006; Meydani, 2009; Antonini et al., 2017).
Fatty acids are the main components of cellular membranes, play a key role in energy homeostasis and take part in oxidative response of the tissues. Fatty acid composition of lipids in the tissues determines the course of a number of metabolic processes in the organism, and the functioning of cellular membranes, inter-cellular signalizing, regulation of gene expression and energy potential of the tissues and the organism in general depend to a high degree on it (Zazharska et al., 2018; Carter et al., 2019; Sobolev et al., 2019). On the other hand, the ability of molecules of fatty acids to oxidize and perform the signal functions is determined by the level of their unsaturation and position of double bonds in these molecules (Skrip \& McWilliams, 2016; Carter et al., 2019). Changes in fatty acid composition, in turn, may be caused by both exo and endogenous factors, i.e. ingression of fatty acids to the organism from diet and transformation of these compounds in the organism with participation of lipogenic enzymes (Shimozuru et al., 2012; Carter et al., 2019). One of the mechanisms of influence of antioxidants on the condition of pro-oxidantantioxidant balance is inhibition of the activity of certain enzymes. The action of natural flavanoids inhibits the synthesis of fatty acids - multienzyme complex that catalyzes the de novo synthesis of fatty acids (Brand et al., 2010; Vauzour et al., 2015; Zhang et al., 2016) and other enzymes of lipid metabolism (Landberg et al., 2020). This may lead to decrease in unsaturation of lipids, and as a result, increase in resistance of the tissues to the action of free radicals. 
Research by Danchenko et al. (2020) revealed specifics of changes in fatty acid composition in the tissues of the brain, liver and skeletal muscles of geese consuming extract of common oat. The research found abnormal fluctuations in fatty acid composition of lipids in these tissues during physiological loading with feather development. However, determining tissue specificity of the effect of the oat extract in this comparison is complicated by presence of multiple factors, as the mentioned tissues differ both histologically and by the level of aerobicity.

Therefore, the objectives of this study were the influence of the extract from common oat $A$. sativa on antioxidant activity and fatty acid composition (FAC) of lipids in the histologically similar tissues of geese which are characterized by different levels of aerobicity (muscles of stomach and cardiac muscle), dynamics of live weight of this bird and pterylographic parameters under physiological loading with growth of contour and juvenile feathers.

\section{Materials and methods}

All the studies were performed according to the requirements of the European Convention for the Protection of Vertebrate Animals used for Experimental and other Scientific Purposes of 1985 and the Law of Ukraine on Protection of Animals Against Abuse from 21.02.2006 No. 3447-IV. The schemes and methods of the studies were approved by the Protocol of the Session of the Commission on Bioethics of Melitopol State Pedagogic University named after Bohdan Khmelnytsky No. 1 from 19.09.2018.

For the studies, we used Danish Legart geese. Geese of this breed have high taste and nutritive parameters of meat with low level of fat and also high-quality and expensive down. These geese are notable for high level of absorption of nutrients while consuming a lower amount of grain fodder compared with traditional breeds of geese. The main mass of fat depositions in Legart geese is located under the skin and does not mix with the muscle fibers (Fedorovich \& Zaplatinsky, 2015).

According to the analogue principle, we composed two groups of geese aged 14 days (control and experimental) with 26 individuals in each. Throughout the study, the birds of the control group were fed with the standard diet, balanced according to the metabolic energy, protein and vitamins according to the recommendations (Ivko et al., 2009).

The young geese of the experimental group were given oat extract from days 14 to 49. To extract phenolic compounds, we used the aboveground part of common oat $A$. sativa in the phase of ear formation and blossom. These compounds were extracted from the raw material using water in the proportion 1:10. Antioxidant activity and fatty acid composition in the muscles of the stomach and cardiac muscle were determined in physiologically substantiated periods: day 14 - end of postnatal adaptation of geese, days 28 and 49 - formation of contour and juvenile feathers respectively, day 56 - presence of the developed plumage, stabilization of pro-oxidant-antioxidant balance.

Intensity of the processes of lipid peroxidation (LPO) was evaluated according to the content of the end products (TBARC) in homogenates of the tissues and in the conditions of LPO of $\mathrm{Fe}^{2+}$ (TBARCs) (Ionov et al., 2011). As an integral parameter of the condition of the system of antioxidative protection (AOS) of the organism of geese, we used coefficient of antioxidant activity (C) (Danchenko et al., 2012). It was calculated as ratio of TBARC to TBARCs, because homogenates of the tissues contain not only substrate of peroxidation, but components of the AOS system which are able to inhibit lipid peroxidation.

Fatty acid composition of lipids was determined using the method of gas-liquid chromatography on a Carlo Erba chromotograph manufactured in Italy. Lipids were extracted using Blight and Dyer technique (Sündermann et al., 2016), preparation of the samples for the analysis, hydrolysis of ethers and methylation of FA were carried out according to the technique (Ichihara \& Fukubayashi, 2010). As a carrier, we used Chromosorb W/DP with phase Silar 5CP (Serva, Germany) in the concentration of $10 \%$ in the temperature of $140-250{ }^{\circ} \mathrm{C}$ and increase rates equaling $2{ }^{\circ} \mathrm{C} / \mathrm{min}$ (the temperature of the injector was $210^{\circ} \mathrm{C}$, and temperature of detector equaled $240^{\circ} \mathrm{C}$ ).

Additionally to the overall content of unsaturated fatty acids (UFA), we calculated the overall equivalent concentration of UFA in relation to double bonds (unsaturation, N) (Danchenko et al., 2003). At the same time, we controlled the dynamics of live weight of geese and their pterylographic parameters.

The results of the study were statistically analyzed using software packs SPSS 11.0 (IBM Corporation, USA). Multiple comparisons of the mean values and inter-group analysis were performed using single-factor dispersion analysis (ANOVA) with calculation of Fisher's F-criteria and application of Tukey test with Bonferroni correction, the differences were considered significant at $\mathrm{P}<0.05$. Mean values and their standard errors are presented in the text and tables in the format $\mathrm{x} \pm \mathrm{SE}$.

\section{Results}

From day 14 to day 28, in the tissues of geese of the control group (no oat extract was added) we observed significant decreases in C, particularly in the muscles of the stomach - by $26.0 \%(\mathrm{P}<0.05)$, in the cardiac muscle - by $39.2 \%(P<0.01$, Table 1$)$. Statistically reliably, $C$ remained at unchanged level in the stomach muscles of 49-day old geese. At the same time, the cardiac muscle of geese of the control group was observed to have a $51.2 \%(\mathrm{P}<0.01)$ increase in this parameter. Transition to day 56 was characterized by increases in $\mathrm{C}$ in both studied tissues: $59.3 \%(\mathrm{P}<$ $0.01)$ in the stomach muscles, and $26.3 \%(\mathrm{P}<0.05)$ in the cardiac muscle.

In 28-day old geese, significant increase in $\mathrm{C}$ level caused by the impact of the extract from oats (experimental group), compared with the control was observed for the cardiac muscle (by $28.3 \%, \mathrm{P}<0.05$ ) and the stomach muscles (by $28.6 \%, \mathrm{P}<0.05$ ). In 49-day old geese, increase in C in both tissues of the experimental group compared with the control was characterized by greater tissue specificity: by $61.3 \%(\mathrm{P}<0.01)$ in the stomach muscles and $23.0 \%(\mathrm{P}<0.05)$ in the cardiac muscle. At the end of the experiment, in 56-day old geese, addition of the oat extract increased the $\mathrm{C}$ level in the stomach muscles compared with the control by $25.8 \%(\mathrm{P}<0.05)$, and at the same time, increase in this parameter in the cardiac muscle was less significant.

Analysis of fatty acid composition of lipids in the stomach muscles of geese of the control group (Table 2) confirms that the overall content of saturated fatty acids (SFA) of lipids in this tissue decreased by $24 \%$ (P < 0.05 ) from day 14 to day 28 and further remained at stable level till the end of the experiment. The highest contents of saturated palmitic (16:0) and stearic (18:0) acids were determined at the beginning of the experiment. From day 14 to day 28 , the contents of these acids in the stomach muscles decreased by $30.7 \%$ and $38.1 \%(\mathrm{P}<0.05)$ respectively and further did not change significantly.

Overall content of unsaturated fatty acids UFA in the stomach muscles of geese of the control group during the first two weeks of the experiment increased by $37.8 \%$, and from the 28 th day remained stable till the end of the experiment. The total content of mono-unsaturated fatty acids MUFA increased by $63.2 \%(\mathrm{P}<0.05)$ from day 14 to day 28 and had a tendency towards growth until the end of the experiment. At the same time, the content of oleic acid $(18: 1)$ increased by $55.4 \%(\mathrm{P}<0.05)$ in the first weeks and the content of palmitic acid (16:1) increased by 2.72 times $(\mathrm{P}<0.01)$. Coefficient of variation of the total content of poly-unsaturated fatty acids PUFA equaled $14.2 \%$ throughout the experiment. The greatest changes in this parameter (tendency towards increase) were observed in the period between days 28 and 49. At the same time, the content of essential linoleic acid (18:2) $\omega 6$ was at stable level throughout the study, and

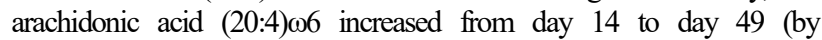
2.13 times) to maximum level with subsequent $25.4 \%$ decrease in the content by the end of the experiment. Content of linolenic (18:3) $\omega 3$ acid, with certain fluctuations (unidentified completely in the stomach muscles of 28-days old geese), increased 4.97-fold from the beginning to the end of the experiment. At the same time, the content docosahexaenoic acid (22:6) $\omega 3$ decreased by 6.13 times during the experiment. Maximum level of the overall unsaturation with N UFA in the stomach muscles was also determined in 56-day old geese.

In the stomach muscles of 28-day old geese of the experimental group, SFA content was $71.1 \%(\mathrm{P}<0.05)$ higher than that of the control group. At the same time, content of palmitic acid (16:0) increased by $80.3 \%$ ( $\mathrm{P}<0.01)$, and stearic acid (18:0) by 2.28 times $(\mathrm{P}<0.01)$. At the same time, UFA content was 2.98 times $(\mathrm{P}<0.01)$ less than that of the 
control group, whereas MUFA in geese of this age in the experimental group decreased by 7.46 times $(\mathrm{P}<0.01)$. Content of oleic acid $(18: 1)$ in the stomach muscles of 28-day old geese of the experimental group was lower by an impressive 47.12 times; palmitoleic acid (16:1) - by 11.59 ; and heptadecene acid (17:1) - by 12.46. PUFA in the stomach muscles of geese of the experimental group was $40.2 \%(\mathrm{P}<0.01)$ lower compared with the control. At the same time, content of linoleic acid (18:2) dropped
3.24 times, and docosahexaenoic acid decreased by 19.08 times. Comparison of the general characteristics of fatty acid compositions (UFA, MUFA, PUFA) of the control and experimental groups of geese on the 49th day of their life indicates that those differences were less significant. We determined a tendency towards increase for $\omega 3$ PUFA due to increase in the contents of linolenic $(18: 3)$ (by 47.8\%) $(\mathrm{P}<0.05)$ and, to a lower degree, docosahexaenoic acids (22:6).

Table 1

Change in coefficient of antioxidant activity $(C)$ in the muscular tissues of Legart geese consuming extract of oat in their diet $(x \pm S E)$

\begin{tabular}{lccccccc}
\hline Variant of the experiment & No oat extract & No oat extract & With oat extract & No oat extract & With oat extract & No oat extract & With oat extract \\
\hline Age of geese, day & $14^{\text {th }}$ & $28^{\text {th }}$ & $28^{\text {th }}$ & $49^{\text {th }}$ & $49^{\text {hh }}$ & $56^{\text {hh }}$ & $56^{\text {h }}$ \\
\hline $\mathrm{n}$ & 6 & 6 & 6 & 6 & 6 & 6 & 6 \\
\hline Stomach muscles & $0.312 \pm 0.012^{a}$ & $0.231 \pm 0.009^{b}$ & $0.297 \pm 0.010^{b}$ & $0.253 \pm 0.011^{a}$ & $0.408 \pm 0.012^{b}$ & $0.403 \pm 0.012^{b}$ & $0.507 \pm 0.010^{b}$ \\
Cardiac muscle & $0.459 \pm 0.011^{a}$ & $0.279 \pm 0.004^{b}$ & $0.358 \pm 0.015^{b}$ & $0.422 \pm 0.008^{b}$ & $0.519 \pm 0.014^{b}$ & $0.533 \pm 0.016^{b}$ & $0.589 \pm 0.031^{a b}$ \\
\hline
\end{tabular}

Note: different letters indicate values that significantly differ one from another within one line of Table 1 according to the results of comparison using the Tukey test $(\mathrm{P}<0.05)$ with Bonferroni correction.

Table 2

Dynamics of fatty acid composition in the stomach muscles of geese consuming oat extract in their diet $(x \pm S E)$

\begin{tabular}{|c|c|c|c|c|c|c|c|}
\hline Variant of the experiment & No oat extract & No oat extract & With oat extract & No oat extract & With oat extract & No oat extract & With oat extract \\
\hline Age of geese, day & $14^{\text {th }}$ & $28^{\text {th }}$ & $28^{\text {th }}$ & $49^{\text {th }}$ & $49^{\text {th }}$ & $56^{\text {th }}$ & $56^{\text {th }}$ \\
\hline $\mathrm{n}$ & 5 & 5 & 5 & 5 & 5 & 5 & 5 \\
\hline 14:0 & $0.371 \pm 0.017^{a}$ & $1.160 \pm 0.073^{b}$ & $0,429 \pm 0.019^{b}$ & $0.234 \pm 0.011^{b}$ & $0.221 \pm 0.009^{a}$ & $0.245 \pm 0.010^{a}$ & $0.331 \pm 0.012^{a}$ \\
\hline 15:0 & $0.079 \pm 0.003^{a}$ & $0.080 \pm 0.002^{a}$ & $0.096 \pm 0.004^{b}$ & $0.098 \pm 0.002^{b}$ & $0.046 \pm 0.001^{b}$ & $0.034 \pm 0.001^{b}$ & $0.048 \pm 0.002^{b}$ \\
\hline $15: 1$ & $0^{a}$ & $0.290 \pm 0.012^{b}$ & $0.130 \pm 0.005^{b}$ & $0^{a}$ & $0.042 \pm 0.002^{a}$ & $0.054 \pm 0.001^{a}$ & $0.105 \pm 0.003^{b}$ \\
\hline 16:0 & $32.51 \pm 1.05^{a}$ & $22.52 \pm 0.96^{b}$ & $40.60 \pm 1.345^{b}$ & $24.18 \pm 1.11^{a}$ & $20.59 \pm 0.89^{a}$ & $23.27 \pm 1.07^{a}$ & $23.96 \pm 0.95^{a}$ \\
\hline $16: 1$ & $0.546 \pm 0.021^{a}$ & $1.483 \pm 0.057^{b}$ & $0.128 \pm 0.004^{b}$ & $1.339 \pm 0.043^{b}$ & $1.001 \pm 0.039^{b}$ & $1.310 \pm 0.053^{a}$ & $2.046 \pm 0.092^{b}$ \\
\hline $17: 0$ & $0.202 \pm 0.009^{a}$ & $0.330 \pm 0.014^{b}$ & $0.110 \pm 0.004^{b}$ & $0.085 \pm 0.003^{b}$ & $0.084 \pm 0.004^{a}$ & $0.088 \pm 0.002^{a}$ & $0.162 \pm 0.005^{b}$ \\
\hline $17: 1$ & $0^{a}$ & $1.109 \pm 0.043^{b}$ & $0.089 \pm 0.003^{b}$ & $0.062 \pm 0.002^{b}$ & $0.083 \pm 0.003^{a}$ & $0.075 \pm 0.002^{a}$ & $0.036 \pm 0.001^{b}$ \\
\hline $18: 0$ & $27.56 \pm 0.95^{a}$ & $17.05 \pm 0.72^{b}$ & $38.86 \pm 1.26^{b}$ & $17.59 \pm 0.85^{a}$ & $18.15 \pm 0.79^{a}$ & $17.76 \pm 0.80^{a}$ & $18.93 \pm 0.86^{a}$ \\
\hline $18: 1$ & $13.55 \pm 0.77^{a}$ & $21.06 \pm 0.93^{b}$ & $0.447 \pm 0.021^{b}$ & $22.12 \pm 0.97^{a}$ & $28.03 \pm 1.01^{b}$ & $25.79 \pm 0.99^{b}$ & $25.54 \pm 0.82^{a}$ \\
\hline $18: 2 \omega 6$ & $9.606 \pm 0.037^{a}$ & $10.13 \pm 0.34^{a}$ & $3.122 \pm 0.014^{b}$ & $10.17 \pm 0.43^{a}$ & $10.54 \pm 0.35^{a}$ & $9.502 \pm 0.407^{a}$ & $8.933 \pm 0.341^{a}$ \\
\hline $18: 3 \omega 3$ & $0.032 \pm 0.006^{a}$ & $0^{b}$ & $0.275 \pm 0.001^{b}$ & $0.069 \pm 0.003^{b}$ & $0.102 \pm 0.004^{b}$ & $0.159 \pm 0.006^{b}$ & $0.152 \pm 0.005^{a}$ \\
\hline $20: 0$ & $0.345 \pm 0.013^{a}$ & $0.440 \pm 0.019^{b}$ & $0.548 \pm 0.024^{b}$ & $0.258 \pm 0.011^{b}$ & $0.372 \pm 0.014^{b}$ & $0.334 \pm 0.009^{b}$ & $0.256 \pm 0.010^{b}$ \\
\hline $20: 1$ & $0.268 \pm 0.011^{a}$ & $0.502 \pm 0.023^{b}$ & $0^{b}$ & $0.290 \pm 0.009^{b}$ & $0.430 \pm 0.017^{b}$ & $0.380 \pm 0.014^{b}$ & $0.354 \pm 0.013^{a}$ \\
\hline $20: 2$ & $0.608 \pm 0.023^{a}$ & $0.311 \pm 0.012^{b}$ & $2.198 \pm 0.103^{b}$ & $0.110 \pm 0.004^{b}$ & $0^{b}$ & $0^{b}$ & $0^{a}$ \\
\hline $20: 3$ & $0.161 \pm 0.007^{a}$ & $0.217 \pm 0.011^{b}$ & $0^{b}$ & $0.333 \pm 0.014^{b}$ & $0.495 \pm 0.019^{b}$ & $0.438 \pm 0.020^{b}$ & $0.302 \pm 0.014^{b}$ \\
\hline $20: 4 \omega 6$ & $5.707 \pm 0.217^{a}$ & $7.930 \pm 0.305^{b}$ & $5.581 \pm 0.208^{b}$ & $12.15 \pm 0.50^{b}$ & $8.544 \pm 0.327^{b}$ & $9.064 \pm 0.401^{b}$ & $9.374 \pm 0.315^{a}$ \\
\hline 21:0 & $0.414 \pm 0.02^{a}$ & $0.331 \pm 0.015^{a b}$ & $0^{b}$ & $0.737 \pm 0.031^{b}$ & $0.741 \pm 0.031^{a}$ & $0.615 \pm 0.028^{b}$ & $0.558 \pm 0.023^{a}$ \\
\hline $22: 0$ & $1.699 \pm 0.06^{a}$ & $1.392 \pm 0.057^{b}$ & $2.237 \pm 0.091^{b}$ & $1.647 \pm 0.049^{b}$ & $1.741 \pm 0.054^{a}$ & $1.963 \pm 0.072^{b}$ & $1.344 \pm 0.053^{b}$ \\
\hline $22: 1$ & $0.132 \pm 0.004^{a}$ & $0.046 \pm 0.002^{a}$ & $1.044 \pm 0.047^{b}$ & $0^{b}$ & $0^{a}$ & $0.149 \pm 0.052^{b}$ & $0^{b}$ \\
\hline $22: 3$ & $0.278 \pm 0.013^{a}$ & $0.363 \pm 0.016^{b}$ & $0.338 \pm 0.015^{a}$ & $0.284 \pm 0.010^{b}$ & $0.404 \pm 0.019^{b}$ & $0.418 \pm 0.020^{b}$ & $0.240 \pm 0.009^{b}$ \\
\hline $22: 4 \omega 6$ & $0^{a}$ & $0^{a}$ & $0^{a}$ & $2.070 \pm 0.098^{b}$ & $2.820 \pm 0.113^{b}$ & $2.554 \pm 0.107^{b}$ & $1.900 \pm 0.073^{b}$ \\
\hline $22: 6 \omega 3$ & $1.809 \pm 0.075^{a}$ & $1.774 \pm 0.069^{a}$ & $0.093 \pm 0.004^{b}$ & $0.367 \pm 0.012^{b}$ & $0.427 \pm 0.009^{a}$ & $0.295 \pm 0.008^{a}$ & $0.247 \pm 0.011^{a}$ \\
\hline $24: 0$ & $0.790 \pm 0.032^{a}$ & $1.406 \pm 0.057^{b}$ & $0^{b}$ & $2.533 \pm 0.103^{b}$ & $1.728 \pm 0.059^{b}$ & $2.006 \pm 0.073^{b}$ & $1.831 \pm 0.077^{a}$ \\
\hline $24: 1$ & $2.107 \pm 0.083^{a}$ & $1.726 \pm 0.073^{b}$ & $1.756 \pm 0.068^{a}$ & $2.706 \pm 0.113^{b}$ & $2.988 \pm 0.105^{a}$ & $2.957 \pm 0.089^{a}$ & $2.792 \pm 0.113^{a}$ \\
\hline SFA, $\%$ & $64.21 \pm 2.05^{a}$ & $48.70 \pm 1.53^{b}$ & $83.44 \pm 3.25^{b}$ & $47.53 \pm 2.01^{a}$ & $43.79 \pm 1.99^{a}$ & $46.44 \pm 2.32^{a}$ & $47.52 \pm 2.02^{a}$ \\
\hline UFA, $\%$ & $34.86 \pm 1.62^{a}$ & $48.02 \pm 2.31^{b}$ & $16.10 \pm 0.74^{b}$ & $52.08 \pm 2.33^{a}$ & $55.91 \pm 2.04^{a}$ & $53.17 \pm 2.20^{a}$ & $52.02 \pm 2.71^{a}$ \\
\hline MUFA, \% & $16.66 \pm 0.79^{a}$ & $27.19 \pm 1.05^{b}$ & $3.646 \pm 0.129^{b}$ & $26.52 \pm 1.01^{a}$ & $32.57 \pm 1.41^{b}$ & $30.74 \pm 1.38^{b}$ & $30.87 \pm 1.32^{a}$ \\
\hline PUFA,\% & $18.20 \pm 0.73^{a}$ & $20.82 \pm 1.00^{a}$ & $12.45 \pm 0.54^{b}$ & $25.56 \pm 0.98^{b}$ & $23.34 \pm 0.97^{a}$ & $22.43 \pm 0.99^{a b}$ & $21.15 \pm 0.96^{a}$ \\
\hline$\omega 3$ PUFA, $\%$ & $2.002 \pm 0.093^{a}$ & $1.990 \pm 0.071^{a}$ & $0.368 \pm 0.014^{b}$ & $0.769 \pm 0.031^{b}$ & $1.024 \pm 0.042^{b}$ & $0.892 \pm 0.038^{a}$ & $0.701 \pm 0.032^{a b}$ \\
\hline$\omega 6$ PUFA, $\%$ & $16.20 \pm 0.82^{a}$ & $18.83 \pm 0.862^{a}$ & $11.38 \pm 0.49^{b}$ & $24.79 \pm 1.00^{b}$ & $22.31 \pm 0.93^{a}$ & $21.54 \pm 1.11^{b}$ & $20.45 \pm 0.96^{a}$ \\
\hline NUFA, mmol/g & $242.3 \pm 11.3^{a}$ & $314.0 \pm 12.5^{b}$ & $133.9 \pm 5.9^{b}$ & $363.2 \pm 15.3^{b}$ & $351.9 \pm 13.3^{a}$ & $339.5 \pm 15.2^{a}$ & $328.8 \pm 15.1^{a}$ \\
\hline
\end{tabular}

Note: different letters indicate values that significantly differ one from another within one line in Table 2 according to the results of comparison using the Tukey test $(\mathrm{P}<0.05)$ with Bonferroni correction.

At the end of the experiment, in the stomach muscles of 56-day old geese of the experimental group, against the background of redistribution of these acids, the content of long-chain acids decreased: behenic acid (22:0) (by $31.5 \%, \mathrm{P}<0.05$ ) and to a less extent arachidonic acid (20:0) (by $23.4 \%$ ); on the other hand, the content of SFA with shorter chain increased: myristic acid (14:0) (by 35.1\%), pentadecylic acid (15:0) (by $41.2 \%, \mathrm{P}<0.05)$ and heptadecanoic acid $(17: 0)$ (by $84.1 \%, \mathrm{P}<0.01$ ). At the same time, the content of palmitic acid (16:0) and stearic acid (18:0) in the muscles of the stomach of the control and experimental groups did not differ significantly. Similar dynamics was also observed among MUFA: against the background of decrease in the content of heptadecene acid (17:1) (by 2.08 times, $\mathrm{P}<0.01$ ), there occurred increases in the contents of pentadecene acid $(15: 1)$ (by $94.4 \%, \mathrm{P}<0.01$ ) and palmitoleic acid (16:1) (by 56.2\%, $\mathrm{P}<0.05$ ). Comparison of the contents of all other groups of fatty acids in the stomach muscles of geese indicates that the difference between the parameters of the control and experimental groups at the final stage of the experiment was not significant.

In the cardiac muscle of geese of the control group (Table 3), the level of SFA underwent no significant changes. The highest content of stearic acid (18:0) in the cardiac muscle was determined in 28-day old geese. The following period of time was characterized by $33.8 \%(\mathrm{P}<0.05)$ fall in the content of this acid (day 49) and its further stabilization at the end of the experiment. Unlike stearic acid, the content of palmitic acid (16:0) was stable throughout the experiment.

UFA content in the cardiac muscles of the control group during the first two weeks of the experiment had a tendency towards decrease, and increased from the 28th to 49th day to the initial level with following stabilization during the last week. The lowest MUFA content was seen in the cardiac muscle of 28-day old geese. From day 28 to day 56, there occurred gradual increase in this parameter (55.1\%) in the control group. 
The lowest amount of oleic acid (18:1) was also determined in 28-day old geese, and from the 28th to 56th day the content of this acid in the cardiac muscle increased by $52.1 \%$. Content of palmitoleic acid (16:1) in the cardiac muscle of geese of the control group decreased by 4.11 times $(\mathrm{P}<$ 0.01 ) from the 14th to 28th day, reaching minimum level, and from day 28 to day 49 increased by 4.58 times $(\mathrm{P}<0.01)$ and stabilized by the end of the experiment. PUFA in the cardiac muscle of geese of the control group was characterized by even lower variability than in the stomach (variation coefficient equaling 11.5\%). The most significant changes in this parameter were observed from the 49th to 56th day. Greatest changes in $\omega 3$ PUFA were determined from the 14 th to 28 th day ( $42.4 \%$ decrease) $(\mathrm{P}<0.05)$, and $\omega 6 \mathrm{PUFA}$ had a tendency towards decrease from the 49th to 56th day. Significant decrease in the content of essential linoleic acid (18:2) (by $34.4 \%, \mathrm{P}<0.05$ ) occurred from day 14 to day 28 , and the content of arachidonic acid (20:4), by contrast, was from the 14th to 28th day observed to have a tendency towards increase up to the maximum value with subsequent decrease to the initial level on the last week of the experiment. The lowest content of linolenic acid (18:3) was determined in the cardiac muscle of 28 -day old geese. From day 28 to day 49, the amount of linolenic acid increased by 2.45 times and stabilized. The most significant changes in docosahexaenoic acid (22:6) $(35.4 \%$ decrease, $\mathrm{P}<0.05)$ was observed at the beginning of the experiment from day 14 to day 28. Maximum level of N UFA in the cardiac muscle was determined in 56-day old geese.

Table 3

Dynamics of fatty acid composition in the cardiac muscle of geese under the effect of the oat extract in their diet $(x \pm S E)$

\begin{tabular}{|c|c|c|c|c|c|c|c|}
\hline Variant of the experiment & No oat extract & No oat extract & With oat extract & With oat extract & With oat extract & No oat extract & With oat extract \\
\hline Age of geese, day & $14^{\text {th }}$ & $28^{\text {th }}$ & $28^{\text {th }}$ & $49^{\text {th }}$ & $49^{\text {th }}$ & $56^{\text {th }}$ & $56^{\text {th }}$ \\
\hline $\mathrm{n}$ & 5 & 5 & 5 & 5 & 5 & 5 & 5 \\
\hline $14: 0$ & $0.431 \pm 0.021^{a}$ & $0.015 \pm 0,006^{b}$ & $0.452 \pm 0.019^{b}$ & $0.274 \pm 0.011^{b}$ & $0.366 \pm 0.015^{b}$ & $0.276 \pm 0.012^{a}$ & $0.270 \pm 0.009^{a}$ \\
\hline 14:1 & $0.011 \pm 0.000^{a}$ & $0^{a}$ & $0.069 \pm 0.002^{b}$ & $0.041 \pm 0.002^{b}$ & $0.024 \pm 0.001^{a b}$ & $0.029 \pm 0.001^{a}$ & $0.031 \pm 0.000^{a}$ \\
\hline $15: 0$ & $0.079 \pm 0.002^{a}$ & $0.030 \pm 0.001^{b}$ & $0.049 \pm 0.002^{b}$ & $0.046 \pm 0.001^{b}$ & $0.058 \pm 0.002^{a b}$ & $0.035 \pm 0.001^{a}$ & $0.030 \pm 0.001^{a}$ \\
\hline $15: 1$ & $0.024 \pm 0.001^{a}$ & $0.022 \pm 0.001^{a}$ & $0.298 \pm 0.014^{b}$ & $0^{a}$ & $0.032 \pm 0.001^{b}$ & $0.011 \pm 0.001^{a}$ & $0^{a}$ \\
\hline $16: 0$ & $21.04 \pm 0.78^{a}$ & $24.08 \pm 1.05^{a b}$ & $42.14 \pm 1.18^{b}$ & $23.06 \pm 0.89^{a}$ & $22.03 \pm 0.93^{b}$ & $24.30 \pm 0.95^{a}$ & $21.68 \pm 1.04^{b}$ \\
\hline $16: 1$ & $2.685 \pm 0.083^{a}$ & $0.654 \pm 0.022^{b}$ & $0.291 \pm 0.016^{b}$ & $2.996 \pm 0.123^{b}$ & $2.970 \pm 0.127^{a}$ & $2.798 \pm 0.133^{a}$ & $2.498 \pm 0.128^{b}$ \\
\hline $16: 2$ & $0.011 \pm 0.000^{a}$ & $0.066 \pm 0.003^{a}$ & $0.192 \pm 0.071^{b}$ & $0^{b}$ & $0^{a}$ & $0.010 \pm 0.000^{a}$ & $0^{a}$ \\
\hline $17: 0$ & $0.101 \pm 0.004^{a}$ & $0.088 \pm 0.003^{a}$ & $0.120 \pm 0.005^{b}$ & $0.075 \pm 0.002^{a}$ & $0.096 \pm 0.003^{a b}$ & $0.067 \pm 0.002^{a}$ & $0.068 \pm 0002^{a}$ \\
\hline $17: 1$ & $0.041 \pm 0.002^{a}$ & $0.067 \pm 0.003^{a}$ & $0.032 \pm 0.001^{b}$ & $0.056 \pm 0.002^{a}$ & $0.064 \pm 0.003^{a}$ & $0.045 \pm 0.002^{a}$ & $0.043 \pm 0.002^{a}$ \\
\hline 18:0 & $19.40 \pm 0.68^{a}$ & $23.45 \pm 1.07^{b}$ & $39.11 \pm 1.94^{b}$ & $15.53 \pm 0.63^{b}$ & $17.35 \pm 0.82^{b}$ & $14.61 \pm 0.53^{a}$ & $13.99 \pm 0.48^{a}$ \\
\hline 18:1 & $25.53 \pm 1.03^{a}$ & $22.82 \pm 0.98^{a b}$ & $0.717 \pm 0.034^{b}$ & $29.66 \pm 1.07^{b}$ & $28.97 \pm 1.07^{a}$ & $34.71 \pm 1.03^{b}$ & $36.59 \pm 1.25^{a}$ \\
\hline $18: 2 \omega 6$ & $17.03 \pm 0.75^{a}$ & $11.17 \pm 0.87^{b}$ & $2.479 \pm 0.136^{b}$ & $12.68 \pm 0.301^{a}$ & $16.28 \pm 0.274^{b}$ & $10.86 \pm 0.41^{b}$ & $10.75 \pm 0.43^{a}$ \\
\hline $18: 3 \omega 3$ & $0.540 \pm 0.023^{a}$ & $0.146 \pm 0.005^{b}$ & $0.070 \pm 0.002^{b}$ & $0.357 \pm 0.012^{b}$ & $0.713 \pm 0.021^{b}$ & $0.378 \pm 0.017^{a}$ & $0.352 \pm 0.019^{a}$ \\
\hline $20: 0$ & $0.515 \pm 0.002^{a}$ & $0.776 \pm 0.032^{b}$ & $0.670 \pm 0.024^{b}$ & $0.426 \pm 0.019^{b}$ & $0.372 \pm 0.009^{a b}$ & $0.288 \pm 0.011^{b}$ & $0.350 \pm 0.017^{a b}$ \\
\hline $20: 1$ & $0.512 \pm 0.021^{a}$ & $0.245 \pm 0.009^{b}$ & $0^{b}$ & $0.302 \pm 0.014^{a b}$ & $0.457 \pm 0.019^{b}$ & $0.259 \pm 0.012^{a b}$ & $0.207 \pm 0.008^{a}$ \\
\hline $20: 2$ & $0.101 \pm 0.003^{a}$ & $0.166 \pm 0.005^{b}$ & $1.480 \pm 0.061^{b}$ & $0.075 \pm 0.002^{b}$ & $0^{b}$ & $0^{b}$ & $0^{a}$ \\
\hline $20: 3$ & $0.281 \pm 0.011^{a}$ & $0.289 \pm 0.013^{a}$ & $0^{b}$ & $0.288 \pm 0.008^{a}$ & $0.243 \pm 0.012^{a}$ & $0.324 \pm 0.009^{a}$ & $0.249 \pm 0.011^{b}$ \\
\hline $20: 4 \omega 6$ & $8.565 \pm 0.341^{a}$ & $11.38 \pm 0.41^{b}$ & $8.908 \pm 0.322^{b}$ & $11.08 \pm 0.27^{a}$ & $7.535 \pm 0.203^{b}$ & $8.417 \pm 0.280^{b}$ & $10.23 \pm 0.38^{b}$ \\
\hline $21: 0$ & $0.572 \pm 0.021^{a}$ & $0.604 \pm 0.029^{a}$ & $0^{b}$ & $0.524 \pm 0.026^{a}$ & $0.394 \pm 0.019^{b}$ & $0.438 \pm 0.020^{b}$ & $0.328 \pm 0.014^{b}$ \\
\hline $22: 0$ & $0.641 \pm 0.025^{a}$ & $0.990 \pm 0.038^{b}$ & $1.749 \pm 0.059^{b}$ & $0.545 \pm 0.018^{b}$ & $0.426 \pm 0.021^{b}$ & $0.469 \pm 0.019^{a b}$ & $0.470 \pm 0.017^{a}$ \\
\hline $22: 3 \omega 6$ & $0.162 \pm 0.008^{a}$ & $0.246 \pm 0.011^{b}$ & $0.179 \pm 0.007^{b}$ & $0.129 \pm 0.005^{b}$ & $0.111 \pm 0.004^{a}$ & $0.126 \pm 0.006^{a}$ & $0.111 \pm 0.005^{a}$ \\
\hline $22: 4 \omega 6$ & $0.244 \pm 0.011^{a}$ & $0.536 \pm 0.023^{b}$ & $0^{b}$ & $0.443 \pm 0.020^{a}$ & $0.291 \pm 0.008^{b}$ & $0.556 \pm 0.023^{b}$ & $0.287 \pm 0.012^{b}$ \\
\hline $22: 6 \omega 3$ & $0.557 \pm 0.013^{a}$ & $0.360 \pm 0.010^{b}$ & $0^{b}$ & $0.524 \pm 0.014^{b}$ & $0.361 \pm 0.009^{b}$ & $0.680 \pm 0.032^{b}$ & $0.578 \pm 0.024^{a b}$ \\
\hline $24: 0$ & $0.348 \pm 0.012^{a}$ & $0.468 \pm 0.019^{b}$ & $0^{b}$ & $0.349 \pm 0.015^{b}$ & $0.299 \pm 0.009^{a b}$ & $0.356 \pm 0.011^{a}$ & $0.328 \pm 0.014^{a}$ \\
\hline $24: 1$ & $0.450 \pm 0.021^{a}$ & $0.752 \pm 0.033^{b}$ & $0.502 \pm 0024^{b}$ & $0.223 \pm 0.013^{b}$ & $0.278 \pm 0.008^{a b}$ & $0.280 \pm 0.012^{a}$ & $0.225 \pm 0.007^{a}$ \\
\hline SFA, $\%$ & $43.18 \pm 1.97^{a}$ & $50.73 \pm 2.38^{b}$ & $84.49 \pm 3.76^{b}$ & $40.93 \pm 1.85^{a}$ & $41.45 \pm 1.79^{a}$ & $40.89 \pm 1.71^{a}$ & $37.63 \pm 1.54^{b}$ \\
\hline UFA, $\%$ & $56.76 \pm 2.32^{a}$ & $48.95 \pm 2.01^{b}$ & $15.33 \pm 0.64^{b}$ & $58.87 \pm 2.39^{b}$ & $58.36 \pm 2.31^{a}$ & $58.93 \pm 2.42^{a}$ & $62.13 \pm 2.72^{b}$ \\
\hline MUFA,\% & $29.27 \pm 1.21^{a}$ & $24.59 \pm 1.32^{b}$ & $2.023 \pm 0.098^{b}$ & $33.30 \pm 1.42^{b}$ & $32.82 \pm 1.62^{a}$ & $38.15 \pm 1.74^{b}$ & $39.60 \pm 1.82^{a}$ \\
\hline PUFA, \% & $27.49 \pm 0.97^{a}$ & $24.36 \pm 0.98^{a b}$ & $13.31 \pm 0.51^{b}$ & $25.57 \pm 1.11^{a}$ & $25.54 \pm 0.92^{a}$ & $20.78 \pm 0.92^{b}$ & $22.57 \pm 0.98^{a b}$ \\
\hline$\omega 3$ PUFA, $\%$ & $1.378 \pm 0.068^{a}$ & $0.794 \pm 0.032^{b}$ & $0.070 \pm 0.003^{b}$ & $1.169 \pm 0.048^{b}$ & $1.317 \pm 0.058^{b}$ & $1.383 \pm 0.061^{b}$ & $1.185 \pm 0.049^{a}$ \\
\hline$\omega 6$ PUFA, $\%$ & $26.11 \pm 0.93^{a}$ & $23.57 \pm 0.93^{a b}$ & $13.24 \pm 0.59^{b}$ & $24.40 \pm 0.98^{a}$ & $24.22 \pm 1.08^{a}$ & $19.40 \pm 0.87^{b}$ & $21.38 \pm 0.95^{a b}$ \\
\hline $\mathrm{NUFA}, \mathrm{mmol} / \mathrm{g}$ & $362.0 \pm 14.2^{a}$ & $339.1 \pm 14.3^{a}$ & $155.5 \pm 7.4^{b}$ & $377.1 \pm 16.5^{a b}$ & $353.3 \pm 13.4^{a b}$ & $406.4 \pm 17.6^{a b}$ & $373.3 \pm 17.3^{a b}$ \\
\hline
\end{tabular}

Note: see Table 2 .

In the cardiac muscle of 28-day old geese of the experimental group, SFA was $66.5 \%(\mathrm{P}<0.05)$ higher than that of the control. At the same time, the concentration of palmitic acid (16:0) increased by $75.0 \%(\mathrm{P}<$ $0.01)$, and stearic acid $(18: 0)$ - by $66.8 \%(\mathrm{P}<0.05)$. Moreover, there occurred statistically significant increases in the contents of myristic acid (by 30.13 times), pentadecylic acid (by $63.3 \%, \mathrm{P}<0.05$ ) and heptadecanoic acid (17:1) (by $36.4 \%, \mathrm{P}<0.01$ ). At the same time, UFA in the cardiac muscle of 28-day old geese of the experimental group was 3.19 lower compared with the control, and MUFA of geese of this age in the experimental group decreased by 12.15 times. Content of oleic acid (18:1) in the stomach muscles of 28-day old geese of the experimental group was lower than that in the control by 31.83 times; palmitoleic acid (16:1) - by 2.24; and heptadecene acid (17:1) - by 2.09. PUFA of the experimental group was by lower $45.4 \%(\mathrm{P}<0.05)$ than the corresponding parameter of the control group. At the same time, the amount of linoleic acid (18:2) decreased by 4.51 times, linolenic acid (18:3) - by 2.09 times, arachidonic acid (20:4) had a tendency towards decrease, and docosatetraenoic (22:4) and docosahexaenoic (22:6) acids were not identified at all. At the same time, in the cardiac muscle of the experimental group, w3PUFA was
11.34 lower than the control, and $\omega 6 \mathrm{PUFA}-$ by $43.8 \%(\mathrm{P}<0.05)$. In the cardiac muscle of 49-day old geese of the control and experimental groups, we determined no significant differences between the general parameters of fatty acid composition (UFA, MUFA, PUFA, w3PUFA and $\omega 6$ PUFA). However, within $\omega 3$ PUFA and $\omega 6$ PUFA, there occurred certain redistribution of acids towards increase in linolenic (18:3) (by 2.00 times) acid and linoleic acid $(18: 2)$ (by $28.4 \%, \mathrm{P}<0.05)$ and decrease in the content of acids with longer chains: arachidonic (20:4) (by 32.0\%, $\mathrm{P}<$ 0.05 ) and docosahexaenoic $(22: 6)$ (by $31.1 \%, \mathrm{P}<0.05)$ acids. At the end of the experiment, in the cardiac muscle of 56-day old geese of the experimental group, the general characteristic of fatty acid composition had no significant differences. Within SFA, against the background of tendency towards decrease in the content of arachidonic (20:0) and behenic (22:0) acids, no significant differences were determined for the contents of palmitic (16:0) and stearic acids (18:0) in the control and experimental groups. At the level of $\mathrm{P}<0.05$, the difference between the abovementioned general parameters of fatty acid compositions of the control and experimental groups was not significant. Among all the changes in the content of individual PUFA under the effect of the extract, at the end of the expe- 
riment, the decrease in the content of docosatetraenoic acid (22:6) (by $48.4 \%, \mathrm{P}<0.05$ ) was significant, though it made no significant difference between $\omega 6$ PUFA of the control and experimental groups.

Comparative analysis of the changes in fatty acid composition at the inter-tissue level confirms that in the cardiac muscle of 14-day old geese of the control group, both UFA (by $62.8 \%, \mathrm{P}<0.05$ ) and MUFA (by $75.7 \%$, $\mathrm{P}<0.05$ ) content exceeded that in the stomach muscles. Furthermore, PUFA in the cardiac muscle was $51.6 \%(\mathrm{P}<0.05)$ higher, and $\omega 6 \mathrm{PUFA}$ was $61.2 \%(\mathrm{P}<0.05)$ higher within PUFA. In 28-day old geese of the control group, significant difference in fatty acid composition at intertissue level was determined only for 133 PUFA (2.41 higher than the stomach muscles). In 49 and 56-day old geese of the control group, no significant difference between the fatty acid composition of the stomach muscles and cardiac muscles were determined.

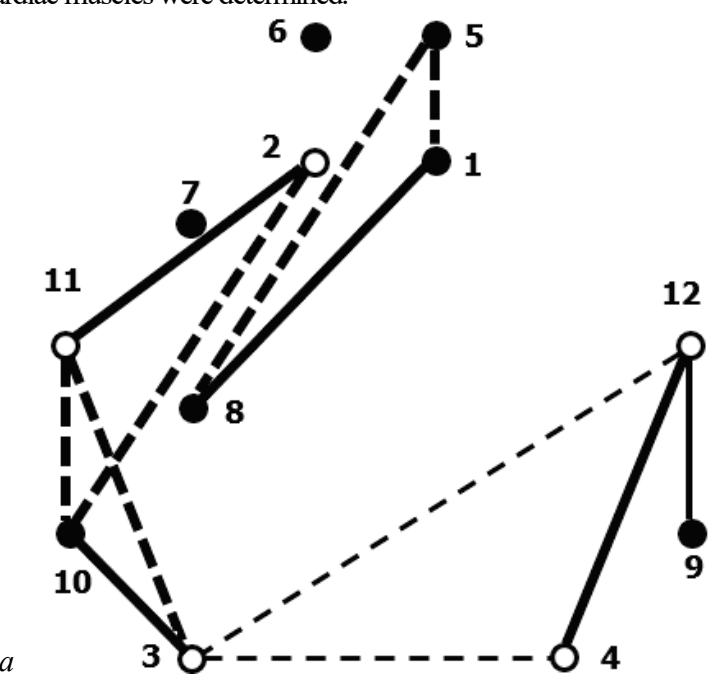

Fatty acid composition of the stomach muscles and the cardiac muscle in the experimental group of 28-day old geese was significantly different by MUFA content (44.5\%, P $<0.05)$, especially $\omega 3$ PUFA $(5.26$ times). Tissue specificity was seen in the changes in the content of linolenic acid (18:3): in the cardiac muscle of 28-day old geese its content decreased by 2.14 times, whereas in the stomach muscles this parameter significantly increased. In 49-day old geese, at inter-tissue level, no significant differences in the fatty acid compositions were determined, and in 56day old geese, only $69.0 \%(\mathrm{P}<0.05)$ excess of $\omega 3$ PUFA in the cardiac muscle was significant.

The results of the correlation analysis we performed indicate that the extract increased the number of significant correlation relationships between fatty acid composition parameters by $33.4 \%$ in the stomach muscles and 2.42 times in the cardiac muscle (Fig. 1, Fig. 2).

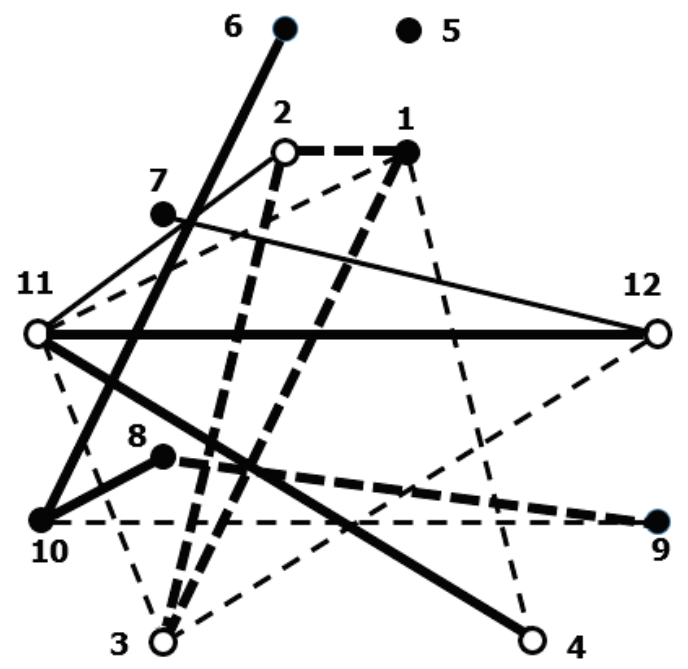

Fig. 1. Clusters for the control group of geese: $a$-the cardiac muscle, $b$ - the stomach muscles; complete lines - positive correlation; dash lines - negative correlation; fat lines - level of significance of the relationships $\mathrm{P}<0.05$, thin lines - level of significance in the relationships $\mathrm{P}<0.10$; indication of fatty acids: (16:0) - 1;(16:1)-2;(18:0)-3;(18:1)-4;(18:2)-5;(18:3)-6;(20:4)-7;(22:4)-8;(22:6)-9; (24:1) - 10; UFA - 11; N UFA - 12
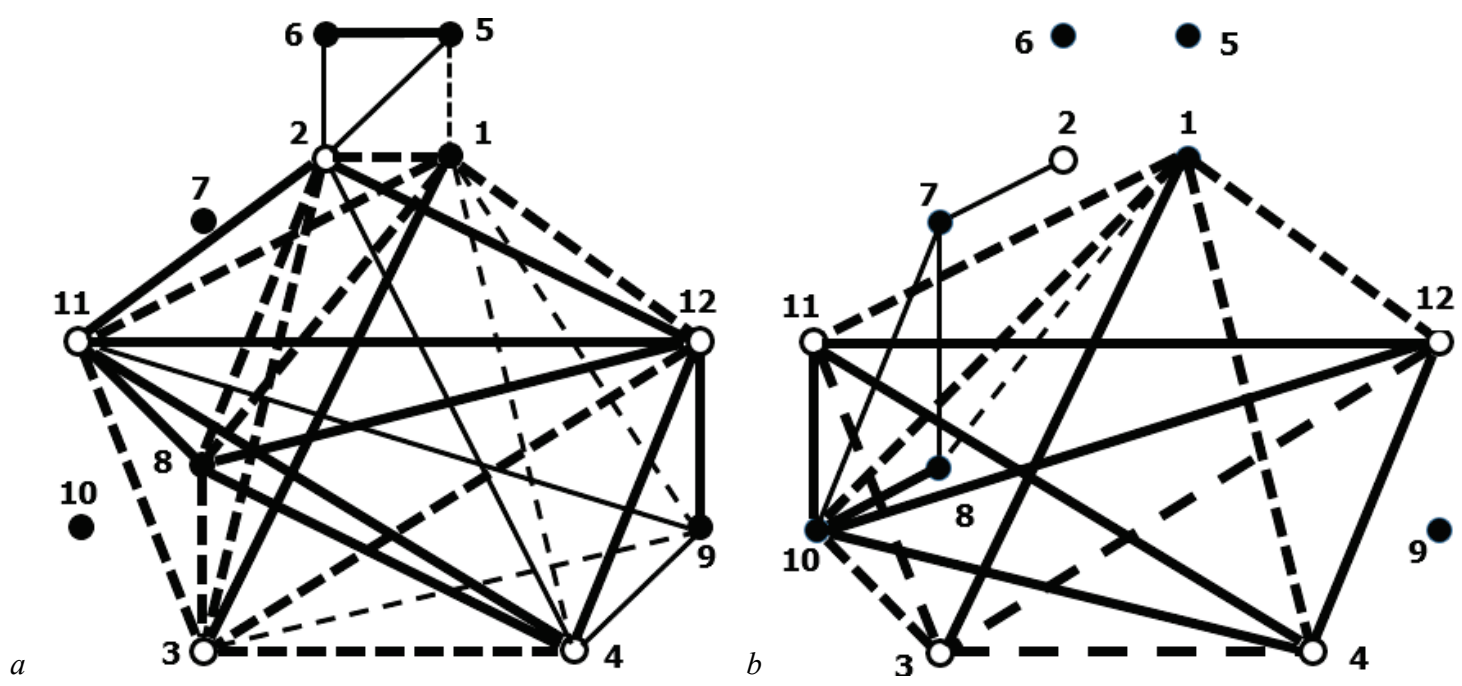

Fig. 2. Clusters for geese that received oat extract: $a$ - the cardiac muscle, $b$ - the stomach muscles; complete lines - positive correlation; dash lines negative correlation; fat lines - level of significance of the relationships $\mathrm{P}<0.05$, thin lines - level of significance of the relationships $\mathrm{P}<0.10$; indications of fatty acids: $(16: 0)-1 ;(16: 1)-2 ;(18: 0)-3 ;(18: 1)-4 ;(18: 2)-5 ;(18: 3)-6 ;(20: 4)-7 ;(22: 4)-8 ;(22: 6)-9 ;(24: 1)-10 ;$ UFA - 11; NUFA - 12

To determine presence and the pattern of the integrated structure of FAC, we performed cluster analysis, the results of which clearly demonstrate the correlation of the dynamics of individual fatty acids (the most content-rich, saturated and unsaturated, essential, $\omega-3$ and $\omega-6$ PUFA) within the studied tissue. Therefore, clusterization of these parameters of the cardiac muscle of the control group geese and the number and density of correlation relationships between them at the level of significance $\mathrm{P}<$ 0.10 allowed us to identify two clusters (Fig. 1a). Within the basic cluster comprising seven parameters, we should note absence of direct relation- ships with essential fatty acids $(5,6,7)$ for the general unsaturation (12), separation of palmitic (1), linoleic (5) and docosatetraenoic (8) acids into a separate cluster and complete absence of significant bonds between linolenic (6) and arachidonic (7) acids. Clusterization of the parameters of the cardiac muscle of the experimental group (at the significance level of $\mathrm{P}<$ 0.10 , Fig. 2a) allowed us to determine that specificity of FAC content dynamics in the cardiac muscle of geese of the experimental group manifested in unification of fatty acids into a single cluster. However, this cluster did not include arachidonic (7) and nervonic (10) acids. In the case of 
presence of significant correlation relationships, FAC parameters in the stomach muscles of geese of the control group were gathered into a cluster (Fig. 1b), which included 11 parameters except linoleic (5) acid. In the stomach muscles of the experimental group, the assemblage of fatty acids into the integral balanced structure remained (Fig. 2b), though linoleic (5), linolenic (6) and docosahexaenoic (9) acids were separated from this cluster. It has to be noted that all four clusters had one common structural group of five FAC parameters, namely: palmitoleic (2), stearic (3) and oleic (4) acids and the total content of UFA (11) and overall unsaturation of fatty acids (12). Insensitivity to the extract of common oat was exhibited by linoleic (5) acid in the stomach tissues (Fig. 1b, 2b) and arachidonic (7) acid in the cardiac muscle (Fig. 1a, 2a). A peculiarity of the dynamics of these acids was absence of statistical relationships with other parameters of FAC in both the control and experimental groups of the geese. Therefore, the action of oat extract activated such mechanisms of antioxidative protection in the cardiac muscle in geese, which increased the level of correlation between changes in fatty acid composition.

Comparative analysis of the general condition and process of the development of feathering of geese of the control and experimental groups at the end of the experiment (at the age of 56 days) revealed the following.

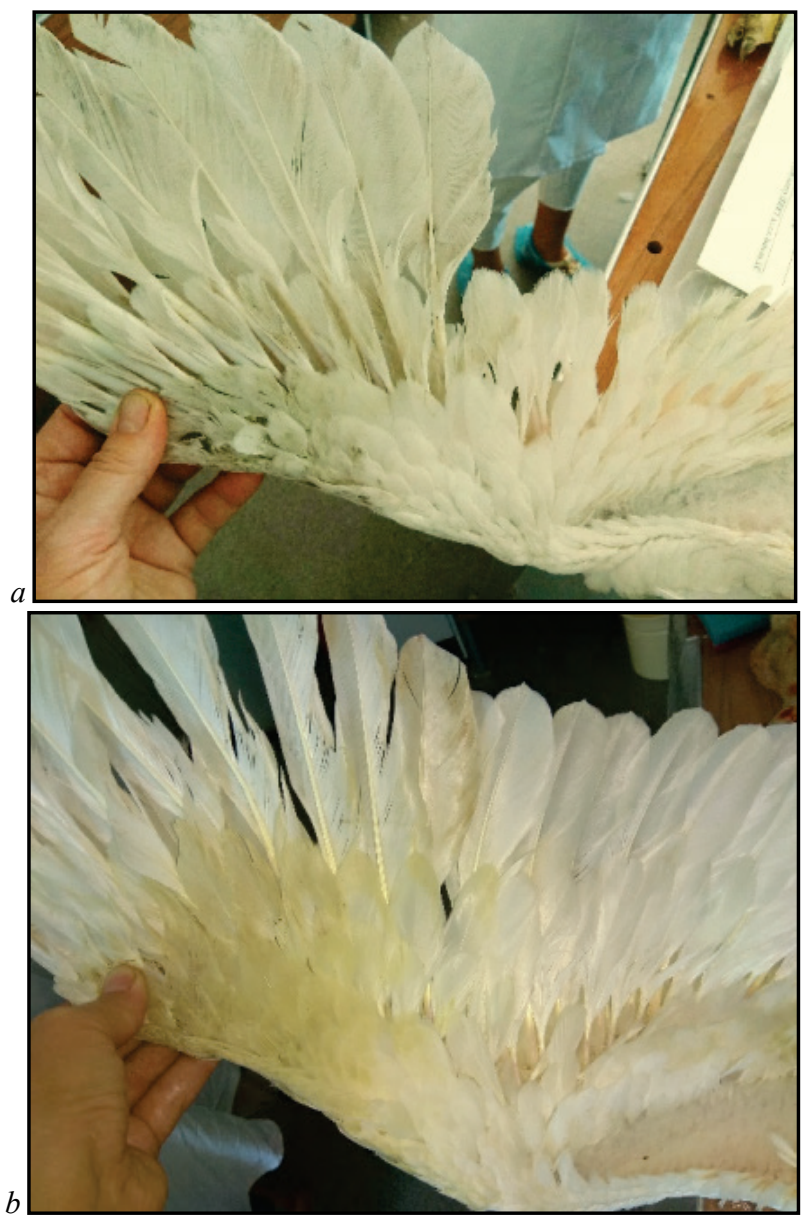

Fig. 3. General view of a wing of a 56-day old goose of the control group $(a)$ and one that received oat extract $(b)$

In the control group, plumage of the birds look untidy, the growth of the feathers of the wings was especially uneven (Fig. 3a). The development of feathers was somewhat slowed, especially in first-row and second-row flight feathers and tail feathers compared with contour feathers, and moreover, the growth of feathers was retarded on the thighs and sides of the torso.

In the experimental group, the plumage in general and some pterylae look healthy and harmoniously developed (Fig. 3b). Nonetheless, flight and tail feathers, as well as feathers on the back, continued to grow. On other pterylae, the development of the feathers was completed, including down feathers and "brush feathers" on the tailbone (coccyx).

\section{Discussion}

Adaptation of geese to the conditions of postnatal existence takes place during the first two weeks of life. The following processes of the formation of first the contour and then juvenile feathers that need significant expenditures of amino acids, including sulfur-containing ones, cause physiological load on the organism of birds and shift in pro-oxidantantioxidant balance towards pro-oxidants. The determined decrease in C from days 14 to 28 in the both studied tissues indicates decrease in the activity of endogenous antioxidants. Completion of feather development in 56-day old geese was accompanied by recovery of the balance between pro- and antioxidants.

The use of antioxidant supplements in the diet is known to significantly weaken the load on the organism of poultry in this period (Ionov et al., 2011; Yakoviichuk et al., 2018). Subject to oat extract, the decrease in antioxidant activity in the tissues of 28-day old geese of the experimental group was less significant. Addition of oat extract led to significant increase in $\mathrm{C}$ in the stomach muscles until the end of the experiment, while increased antioxidant activity was observed in the cardiac muscle throughout the experiment. One of the mechanisms of increasing antioxidant status of the tissues of a functioning organism under physiological loading may be the decrease in the content of the main substrate of peroxidation of lipids of unsaturated fatty acids, and therefore, increase in resistance of lipids of biomembranes to oxidative damage (Zdorovtseva et al., 2012). Identification of changes in fatty acid composition during growth of contour and juvenile feathers allowed us to determine the level of effect of this mechanism on increase in adaptive potencies of geese in the indicated period of their development.

Analysis of fatty acid composition of the examined tissues of 14 and 28-day old geese of the control group confirms the presence of certain changes throughout the third and forth weeks of postnatal development, but these differences were insignificant compared to the difference between fatty acid compositions in 28-day old geese of the control and experimental groups. First of all, we should note rapid decrease in the total content of UFA and unsaturation of fatty acids under the effect of the extract in both studied tissues of 28-day old geese. Therefore, increase in antioxidant activity occurs as a result of fall in the total content of UFA, as well as selective metabolism of UFA, oriented towards decrease in the content of poly-unsaturated fatty acids (PUFA) and likely implemented through inhibition of synthesis of fatty acids and blocking of the expression of genes of other enzymes of lipid metabolism (Tian, 2006; Damiano et al., 2019). Rapid decrease in the content of oleic acid (18:1) in the cardiac muscle and the stomach muscles of 28-day old geese of the experimental group may be considered as a mechanism of reducing the content of the substrate of peroxidation. Most cells of eukaryotes are able to de novo synthesize fatty acids from glucose (Gula \& Margitich, 2009). Palmitic acid (16:0), which is a product of such a synthesis, under the effect of stearoyl-CoA desaturase ( $\Delta 9$-desaturase) and elongase Elovl-6, transforms into one of the main components of triacylglycerols of fatty tissues of animals - oleic acid. Malfunctioning of oleic acid synthesis caused by defects of $\Delta 9$-desaturase is known to have negative effects such as inhibition of triacylglycerols synthesis, activation of processes of oxidation of fatty acids, etc. However, short term inhibition of synthesis of oleic acid may be the mechanism of reducing the content of substrate of lipid peroxidaton, and therefore ability of the tissues to undergo this type of oxidation.

The reason for significant decrease in the content of linoleic acid (18:2) in both the studied tissues of 28-day old geese subjected to effect of the extract may be the activation of the processes of synthesis of arachidonic acid from it (20:4) with participation of elongases (Elovl-2 i -5) and desaturases ( $\Delta 5$ - and $\Delta 6$-desaturases), because this acid (20:4) is a predecessor of eicosanoids that are important regulators of metabolic processes in the organism. This presumption is supported by the relatively small amount of arachidonic acid in both studied tissues against the background of physiological loading with contour feather formation.

Moreover, tissue specificity was seen in changes in the contents of linolenic (18:3) and docosahexaenoic (22:6) acids. While the content of linolenic acid in the cardiac muscle of 28-day old geese decreased by 2.14 times, in the stomach muscles this parameter significantly increased. 
Subject to the effect of the extract, the content of docosahexaenoic acid in the stomach muscles decreased by 19.7 times, and vanished entirely in the cardiac muscle. Nonetheless, comparison of the changes in fatty acid compositions in the stomach and cardiac muscles of the experimental group of geese indicated that the mechanism of antioxidant effect of the extract within the conducted experiment was not tissue-specific, for the main orientations of the changes in the fatty-acid content during development of feathers in 28-day old geese were determined in both examined tissues.

Thus, physiological loading on the organism of geese related to the growth of contour feathers was significantly reduced by the influence of the oat extract through activation of regulatory mechanisms that had selectively inhibited UFA synthesis. First of all, this was relevant for $\Delta-9$ desaturase that takes part in the synthesis of oleic acid (Dalla et al., 2019). At the same time, the activation of elongases involved in the synthesis of palmitic and stearic acids may have occurred. Comparative analysis of changes in the overall content of UFA in the examined tissues of 28-day old geese consuming oat extract indicates their similarity. Nonetheless, at the level of individual acids, first of all, essential, the research confirmed a certain tissue specificity of those changes which lies in the differently oriented changes in the content of linolenic acid in the context of decreases in the amounts of linoleic and arachidonic acids in both examined tissues.

Further changes in FAC, accompanied by growth of juvenile feathers, in 49-day old geese were characterized by equalizing of the fatty acid contents in the control and experimental groups, first of all, through increase in the content of oleic acid, and by contrast decreases in the content of palmitic and stearic acids. More significant differences in the tissues of 49-day old geese of the control and experimental groups were determined for PUFA in the cardiac muscles (increases in the contents of linoleic and linolenic acids and decreases in the levels of arachidonic and docosahexaenoic acids). It has to be noted that according to the results published earlier, a similar effect of the extract was seen in the liver tissues as well (Danchenko et al., 2020).

Thus, antioxidant action of the extract also expressed during the growth of juvenile feathers. However, the mechanisms of this effect at the stage of the development of juvenile feathers are different, as confirmed by the great decrease in the significant difference between the fatty acid composition in the stomach and cardiac muscles of 49-day old geese of the control and experimental groups.

Recovery of pro-oxidant-antioxidant balance in 56-day old geese, which indicates the completion of the processes of development of feathers, was characterized by gradual stabilization of the total content of UFA and unsaturation of lipids in the studied tissues. Therefore, antioxidant activity of the oat extract at earlier stages of the growth of bird organism manifested in selective modulation of synthesis or oxidation of fatty acids.

According to domestic and foreign biochemists (Rostova, 2002; Danchenko, 2009; Yakoviichuk et al., 2018), one of the mechanisms of increasing the efficiency of functioning of any system of the organism, including antioxidant, may be increasing the level of balance in the dynamics of its parameters.

The results of the conducted correlation analysis confirmed that the amount of significant correlation relationships between the FAC parameters of geese in the experimental group increased by $33.4 \%$ in the stomach muscles and 2.42 times in the cardiac muscle compared with the control. Thus, in the stomach and cardiac muscles of geese, extract of oat activated mechanisms of antioxidant protection, which increases the level of correlation between the changes in fatty acid composition.

Control of the dynamics of weight of geese throughout the experiment indicates a certain tendency towards increase in the weight of geese of the experimental group compared with the control. Nevertheless, the mass of the geese of the experimental group became significantly greater (by 17.9\%) compared with the control only at the end of the experiment at the age of 56 days and this is further evidence of activation of antioxidative protection of geese which consume oat extract.

\section{Conclusions}

Thus, subject to the influence of oat extract, physiological loading in the stomach muscles and the cardiac muscles during the growth of con- tour feathers significantly weakens through selective inhibition of synthesis of unsaturated fatty acids. Increase in antioxidative activity in these tissues in geese during the development of juvenile feathers occurs as a result of activation of alternative mechanisms of antioxidative protection, which are implemented without significant changes in the fatty acid composition. Components of the oat extract activated antioxidative protection mechanisms that increase specifically the level of correlation between changes in the parameters of fatty acid composition. Extract of oat statistically significantly increased the weight at the end of the experiment and improved their pterylographic parameters. Therefore, it is recommended to use oat extract in feeding both poultry and wild species grown for hunting, which is perfectly suitable for their further release into the wild.

The studies were carried out within the Program of Scientific-Research Work No. 0118U004186 "Biochemical and technological aspects of the protection of the environment and its computer monitoring".

\section{References}

Aldubayan, M. A., Elgharabawy, R. M., Ahmed, A. S., \& Tousson, E. (2019). Antineoplastic activity and curative role of avenanthramides against the growth of ehrlich solid tumors in mice. Oxidative Medicine and Cellular Longevity, 2019, $1-12$.

Antonini, E., Diamantini, G., \& Ninfali, P. (2017). The effect of mechanical processing on avenanthramide and phenol levels in two organically grown Italian oat cultivars. Journal of Food Science and Technology, 54(8), 2279-2287.

Brand, W., Boersma, M. G., Bik, H., Hoek-van den Hil, E. F., Vervoort, J., Barron, D., Meinl, W., Glatt, H., Williamson, G., van Bladeren, P. J., \& Rietjens, I. M. C. M. (2010). Phase II metabolism of hesperetin by individual UDP-glucuronosyltransferases and sulfotransferases and rat and human tissue samples. Drug Metabolism and Disposition, 38(4), 617-625.

Chen, C., Li, T., Chen, Z., Wang, L., \& Luo, X. (2020). Absorption rates and mechanisms of avenanthramides in a caco- 2 cell model and their antioxidant activity during absorption. Journal of Agricultural and Food Chemistry, 68(8), 23472356.

Chen, C., Wang, L., Wang, R., Luo, X., Li, Y., Li, J., \& Chen, Z. (2018). Phenolic contents, cellular antioxidant activity and antiproliferative capacity of different varieties of oats. Food Chemistry, 239, 260-267.

Christensen, R. (2018). Analysis of variance, design, and regression. Chapman and Hall/CRC, London.

Dalla Valle, A., Vertongen, P., Spruyt, D., Lechanteur, J., Suain, V., Gaspard, N., Brion, J.-P., Gangii, V., \& Rasschaert, J. (2019). Induction of stearoyl-coa 9-desaturase 1 protects human mesenchymal stromal cells against palmitic acid-induced lipotoxicity and inflammation. Frontiers in Endocrinology, 10, 726.

Damiano, F., Giannotti, L., Gnoni, G. V., Siculella, L., \& Gnoni, A. (2019). Quercetin inhibition of SREBPs and ChREBP expression results in reduced cholesterol and fatty acid synthesis in C6 glioma cells. The International Journal of Biochemistry and Cell Biology, 117, 105618.

Danchenko, O. O. (2009). Riven' uzgodzhenosti pokaznykiv pro-antyoksydantnoji rivnovagy pechinky gusej jak kryterij poshkodzhujuchogo vplyvu tehnologichnyh chynnykiv [The level of consistency of pro-antioxidant balance of goose liver as a criterion for the damaging effects of technological factors]. Scientific Messenger of Lviv National University of Veterinary Medicine and Biotechnologies, Veterinary Sciences, 11(3), 26-34 (in Ukrainian).

Danchenko, O. O., Pashhenko, Y. P., Danchenko, N. M., \& Zdorovceva, L. M. (2012). Mehanizmy pidtrymky prooksydantno-antyoksydantnoji rivnovagy v tkanynah pechinky gusej v umovah gipo- $\mathrm{i}$ giperoksiji [Mechanisms of support prooxidant-antioxidant balance in the liver tissues of geese in hypo- and hyperoxia]. Ukrainskyi Biokhimichnyi Zhumal, 84(6), 109-114 (in Ukrainian).

Danchenko, O., Zdorovtseva, L., Vishchur, O., Koshelev, O., Halko, T., Danchenko, M., Nikolayeva, Y., \& Mayboroda, D. (2020). Extract of oats as a modulator of fatty acid composition of geese tissues in the conditions of physiological stress. Biologija, 66(1), 27-34.

Danchenko, O. O., Kalytka, V. V., \& Kolesnic, D. M. (2003). Ontogenetychni osoblyvosti zmin zhymokyslotnogo skladu lipidiv pechinky gusej jak golovnogo substratu peroksydaciji [Ontogenic characteristics of changes in fatty acid composition of the liver lipids as a main substrate for peroxidation in geese]. Ukrainskyi Biokhimichnyi Zhumal, 75(3), 124-129 (in Ukrainian).

De Bruijn, W. J. C., van Dinteren, S., Gruppen, H., \& Vincken, J.-P. (2019). Mass spectrometric characterisation of avenanthramides and enhancing their production by germination of oat (Avena sativa). Food Chemistry, 277, 682-690.

Fedorovich, E. I., \& Zaplatinsky, V. S. (2015). Suchasnyj stan ta perspektyvy rozvytku gusivnyctva Ukrajiny [Current situation and perspectives of goose farming in Ukraine]. Scientific Messenger of Lviv National University of Veteri- 
nary Medicine and Biotechnologies, Veterinary Sciences, 17(3), 322-329 (in Ukrainian).

Gula, N. M., \& Margitich, V. M. (2009). Zhyrni kysloty ta jih pohidni pry patologichnyh stanah [Fatty acids and their derivatives in pathological conditions]. Naukova Dumka, Kyiv (in Ukrainian).

Hanikoglu, A., Kucuksayan, E., Hanikoglu, F., Ozben, T., Menounou, G., Sansone, A., Chatgilialoglu, C., Di Bella, G., \& Ferreri, C. (2020). Effects of somatostatin, curcumin, and quercetin on the fatty acid profile of breast cancer cell membranes. Canadian Journal of Physiology and Pharmacology, 98(3), 131-138.

Ichihara, K, \& Fukubayashi, Y. (2010). Preparation of fatty acid methyl esters for gas-liquid chromatography. Journal of Lipid Research, 51(3), 635-640.

Ionov, I. A., Shapovalov, S. O., Dolgaya, M. N., Akhtyrsky, A. V., Zozulya, Y. A., Komisova, T. E., \& Kostyuk, I. A. (2011). Opredelenie malonovogo dial'degida $\mathrm{v}$ tkanjah i organah [Determination of malondialdehyde in tissues and organs]. In: Kriterii i metody kontrolja metabolizma v organizme zhivotnyh i ptic [Criteria and methods for controlling metabolism in animals and birds]. Institute of Animal Husbandry National Academy of Agrarian Science, Kharkov. Pp. 224-225 (in Russian).

Ivko, I. I., Mykytiuk, D. M., Melnyk, V. O., Riabinina, O. V., \& Bratyshko, N. I. (2009). Rekomendatsiji shchodo spriamovanoho vyroshchuvannia, utrymannia i vidhodivli vodoplavnoi ptytsi [Recommendations for targeted breeding, keeping and fattening of waterfowl]. Institute of Poultry National Academy of Agrarian Science, Birky (in Ukrainian).

Jágr, M., Dvořáček, V., Čepková, P. H., \& Doležalová, J. (2020). Comprehensive analysis of oat avenanthramides using hybrid quadrupole-Orbitrap mass spectrometry: Possible detection of new compounds. Rapid Communications in Mass Spectrometry, 34(10), e8718.

Landberg, R., Sunnerheim, K., \& Dimberg, L. H. (2020). Avenanthramides as lipoxygenase inhibitors. Heliyon, 6(6), e04304.

Ltaif, M., Gargouri, M., Magné, C., Feki, A., \& Soussi, A. (2020). Protective effects of Avena sativa against oxidative stress-induced kidney damage resulting from an estrogen deficiency in ovariectomized Swiss mice model. Joumal of Food Biochemistry, 44(6), e13205.

Meydani, M. (2009). Potential health benefits of avenanthramides of oats. Nutrition Reviews, 67(12), 731-735.

Montilla-Bascón, G., Broeckling, C. D., Hoekenga, O. A., Prats, E., Sorrells, M., \& Isidro-Sánchez, J. (2017). Chromatographic methods to evaluate nutritional quality in oat. Methods in Molecular Biology, 1536, 115-125.

National Research Council (1994). Nutrient requirements of poultry. Ninth edition. The National Academies Press, Washington.

Nie, L., Wise, M. L., Peterson, D. M., \& Meydani, M. (2006). Avenanthramide, a polyphenol from oats, inhibits vascular smooth muscle cell proliferation and enhances nitric oxide production. Atherosclerosis, 186(2), 260-266.

Pridal, A. A., Böttger, W., \& Ross, A. B. (2018). Analysis of avenanthramides in oat products and estimation of avenanthramide intake in humans. Food Chemistry, 253, 93-100.
Rostova, N. S. (2002). Korreljacii: Struktura i izmenchivost' [Correlations: Structure and variability]. Publishing house of Saint Petersburg State University, Saint Petersburg (in Russian).

Singh, R., De, S., \& Belkheir, A. (2013). Avena sativa (oat), a potential neutraceutical and therapeutic agent: An overview. Critical Reviews in Food Science and Nutrition, 53(2), 126-144.

Sobolev, O. I., Gutyj, B. V., Sobolieva, S. V., Shaposhnik, V. M., Sljusarenko, A. A., Stoyanovskyy, V. G., Kamratska, O. I., Karkach, P. M., Bilkevych, V. V., Stavetska, R. V., Babenko, O. I., Bushtruk, M. V., Starostenko, I. S., Klopenko, N. I., Korol'-Bezpala, L. P., \& Bezpalyi, I. F. (2019). Digestibility of nutrients by young geese for use of lithium in the composition of fodder. Ukrainian Journal of Ecology, 9(1), 1-6.

Soycan, G., Schär, M. Y., Kristek, A., Boberska, J., Alsharif, S. N. S., Corona, G., Shewry, P. R., \& Spencer, J. P. E. (2019). Composition and content of phenolic acids and avenanthramides in commercial oat products: Are oats an important polyphenol source for consumers? Food Chemistry, 10(3), 100047.

Sumayya, P. C., Babu, G. M., \& Muraleedharan, K. (2021). Quantum chemical investigation of the antiradical property of avenanthramides, oat phenolics. Heliyon, 7(2), e06125.

Tian, W. X. (2006). Inhibition of fatty acid synthase by polyphenols. Current Medicinal Chemistry, 13(8), 967-977.

Vauzour, D., Tejera, N., O’Neill, C., Booz, V., Jude, B., Wolf, I. M. A., Rigby, N., Silvan, J. M., Curtis, P. J., Cassidy, A., de Pascual-Teresa, S., Rimbach, G., \& Minihane, A. M. (2015). Anthocyanins do not influence long-chain n-3 fatty acid status: Studies in cells, rodents and humans. The Journal of Nutritional Biochemistry, 26(3), 211-218.

Walsh, J., Haddock, J., Blumberg, J. B., McKay, D. L., Wei, X., Dolnikowski, G., \& Chen, C.-Y. O. (2017). Identification of methylated metabolites of oat avenanthramides in human plasma using UHPLC QToF-MS. International Joumal of Food Sciences and Nutrition, 69(3), 377-383.

Yakoviichuk, O., Danchenko, O., Kurtyak, B., Nikolaeva, Y., Fedorko, A., \& Halko, T. (2019). Ontogenetic features of redox reactions in the myocardium of geese. Biologija, 64(4), 259-266.

Zazharska, N., Boyko, O., \& Brygadyrenko, V. (2018). Influence of diet on the productivity and characteristics of goat milk. Indian Joumal of Animal Research, 52(5), 711-717.

Zdorovtseva, L. M., Khromishev, V. O., \& Danchenko, O. O. (2012). Zhyrnokyslotnyj sklad lipidiv mozku i sercja gusej v umovah gipo- $\mathrm{i}$ giperoksiji [Fatty acid composition of brain and heart lipids of geese in hypo- and hyperoxia]. Biological Bulletin of Bogdan Khmelnitsky Melitopol State Pedagogical University, 2(3), 9-18 (in Ukrainian).

Zhang, J. S., Lei, J. P., Wei, G. Q., Chen, H., Ma, C. Y., \& Jiang, H. Z. (2016). Natural fatty acid synthase inhibitors as potent therapeutic agents for cancers: A review. Pharmaceutical Biology, 54(9), 1919-1925.

Zhang, T., Shao, J., Gao, Y., Chen, C., Yao, D., Chu, Y. F., Johnson, J., Kang, C., Yeo, D., \& Ji, L. L. (2017). Absorption and elimination of oat avenanthramides in humans after acute consumption of oat cookies. Oxidative Medicine and Cellular Longevity, 2017, 2056705. 